\title{
J22 燃料噴霧の測定データに基づくディーゼル機関燃焼解析 \\ Numerical analysis of diesel combustion based on the spray model verified by L2F
}

$\begin{array}{llrlll}\text { 学 アミダ オルウォレ(長崎大院) } & \text { ○学 } & \text { 箈瀬 } & \text { 祥隆 } & \text { （長崎大院） } \\ \text { 正 植木 弘信 (長崎大) } & \text { 正 } & \text { 石田 } & \text { 正弘 (長崎大) } \\ \text { 正 坂口 大作 (長崎大) } & & & & \end{array}$

Oluwole AMIDA ,Yoshitaka YANASE , Hironobu UEKI, Masahiro ISHIDA, Daisaku SAKAGUCHI Nagasaki University, 1-14 Bunkyo-Machi, Nagasaki 852-8521

Key Words : Diesel Engine, Droplet Breakup, L2F, Numerical Simulation

1. まえがき

ディーゼル機関の性能向上ならびに排気特性改善には燃 焼現象の把握とともに数值解析が有効であり、燃焼室のガス 流動、燃料噴霧液滴の分裂・合体・蒸発および燃焼を 3 次元・ 非定常・乱流の条件で解析する数值解析コード KIVA-3 $3^{(1)}$,(2) は標準的ツールの一つである。燃料噴霧特性はディーゼル機 関の燃焼を支配する最も重要なパラメータであり、燃焼解析 においては噴霧モデルの構築ならびにその検証が不可欠で ある。

著者らは $2 つ の$ 焦点の間を液滴が飛行する時間を計測し て速度を求めるレーザ 2 焦点流速計 (L2F; Laser 2-Focus velocimeter）に散乱時間計測機能を付加することにより噴 霧液滴の速度とサイズの同時計測を行った ${ }^{(3)}$ 。この計測デー 夕を基に本研究では噴霧液滴分裂モデルとして KH-RT モデル を使用し噴霧分裂パラメータが噴霧解析および然焼解析に 及ぼす影響を調查した。

\section{2. 実験方法および計測方法}

\subsection{L2F による噴霧計測}

噴霧液滴の速度およびサイズの計測には 2 焦点間隔が $20 \mu \mathrm{m}$ 、 焦点直径が約 $2 \mu \mathrm{m}$ の $\mathrm{L} 2 \mathrm{~F}$ を用いた。レール圧を $40 \mathrm{MPa}$ に設定 したコモンレールシステムを用いて軽油を大気中に間欠噴 射した。燃料噴射ノズルの噴孔径は $0.113 \mathrm{~mm}$ である。L2Fに よる計測は、噴孔出口からの距離 $\mathrm{z}$ を噴霧軸方向にとり、 $z=10,15,20,25,30 \mathrm{~mm}$ の 5 点で行い、各計測点でそれぞれ 30,000 点のデータを取得した。

\section{2 ディーゼル機関燃焼試験}

ボア $102 \mathrm{~mm}$ 、ストローク $105 \mathrm{~mm}$ 、圧縮比 17.8 の単気筒ディ 一ゼル機関（ヤンマーディーゼル製 NFD-170(E)）を用いて燃 焼時間履歴を計測した。表 1 に供試機関の主要仕様を示す。

\section{3. 解析方法}

KIVA-3V の噴霧分裂モデルとして $\mathrm{KH}-\mathrm{RT}^{(4)}$ モデルを用いて 噴霧液滴分裂過程およびディーゼル燃焼の数值解析を行っ た。噴霧解析および燃焼解析に用いた解析格子を図 1 (a) およ び (b)に示す。周 $(\theta)$ 方向、半径 $(r)$ 方向、および噴射軸 $(z)$ 方 向にそれぞれ $21 、 51 、$ 打よび 83 をとり、総格子数を 110,058 とした。燃料としてテトラデカン $\left(\mathrm{C}_{14} \mathrm{H}_{30}\right)$ を使用し、総パーセ ル数を 5,000 とした。本研究では、初期夜滴サイズをノズル 出口径になるように設定した。

本研究では、噴孔出口からの距離が分裂長さ以下では WAVE モデルを、分裂長さを超えた領域では、WAVE モデルとRT モ デルを組み合わせて使用した。分裂長さ $L b$ は Levich 理論よ り、

$$
L b=C_{b} d_{0} \sqrt{\frac{\rho_{f}}{\rho_{a}}}
$$

と定義される。 $d_{0}$ はノズル直径であり、 $\rho_{f}$, および $\rho_{a}$ はそ れぞれ燃料および空気の密度を表す。実験定数 $C_{b}$ は、
$C_{b}=0.5 B_{1}$

として与えた ${ }^{(5)} B B I$ は液滴の分裂時間を決定する定数であり、 $B 1$ が小さくなるほど、分裂時間が短くなり、分裂が早期に完 了する。

\section{4. 結果および考察}

図2(a)㧍よび(b)はそれぞれ噴霧頭部における液滴速度およ び液滴サイズの算術平均の軸方向変化を示す。丸印は L2Fに よる測定結果を示し、実線は $B I=10$ を、破線は $B I=40$ による 数值解析結果を示す。液滴速度の解析結果は測定值に比べ大 きく見積もられている。また、測定された液滴サイズに対し て $B I=10$ による解析結果が分裂長さ以降で比較的計測結果に 近い値を示している。

図3(a)および (b) はそれぞれ $\mathrm{z}=30 \mathrm{~mm}$ の噴霧軸上における液 滴速度と液滴サイズの噴霧頭部における確率密度分布を示 す。 $B I=10$ の解析結果による液滴速度の広がりがL2Fによる計 測結果より狭くなっている。分裂の進行が遅い $B 1=40$ のサイ ズ分布に比べて $B I=10$ の解析結果が測定結果に近い値となっ ている。

図4はKIVA-3Vによる燃焼解析で得られた熱発生率と実験 結果の比較である。解析結果は $B I=10$ および $B I=40$ の場合とも に熱発生率のピークが実験值より過大に見積もられている。 また実験結果に比べ $B 1=40$ 着火遅れが短くなっている。

Table 1 Specifications of test engine

\begin{tabular}{|c|c|}
\hline Type of engine & YANMAR NFD170-(E) \\
\hline Cycle & 4 \\
\hline Number of cylinder & 1 \\
\hline Cooling system & Water \\
\hline Bore S Stroke & $102.0 \times 105.0(\mathrm{~mm})$ \\
\hline Piston displacement & $857(\mathrm{cc})$ \\
\hline Compression ratio & 17.8 \\
\hline Maximum power & $12.5(\mathrm{KW}) / 2400(\mathrm{rpm})$ \\
\hline Nozzle hole diameter & $0.29(\mathrm{~mm})$ \\
\hline Number of Nozzle holes & 4 \\
\hline Injection timing & $-5^{\circ}$ BTDC \\
\hline
\end{tabular}

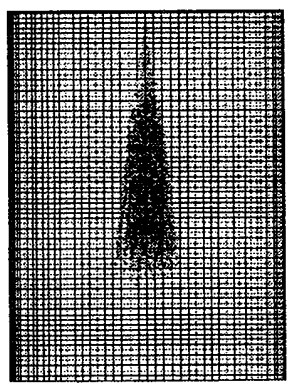

(a) Spray Simulation

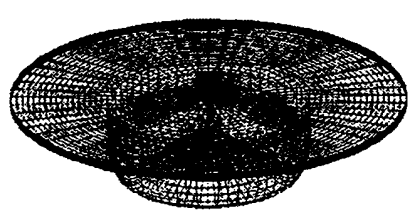

(b) Combustion Simulation Fig. 1 Mesh 


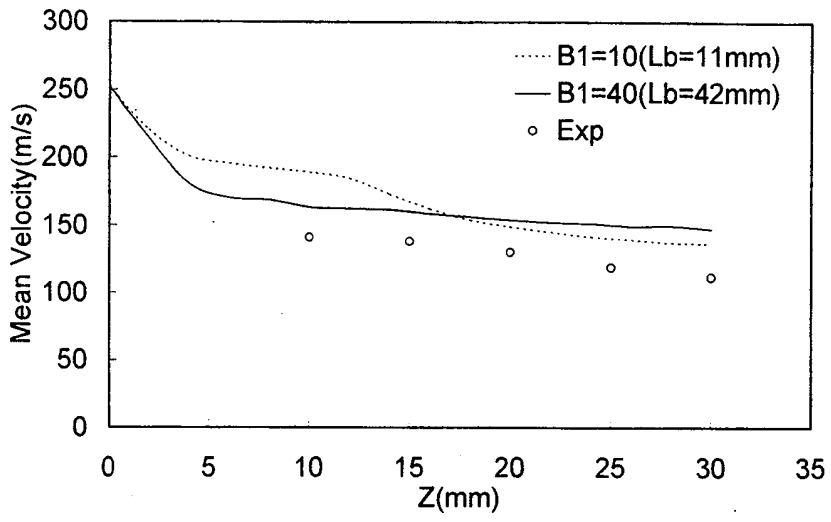

(a) Mean velocity

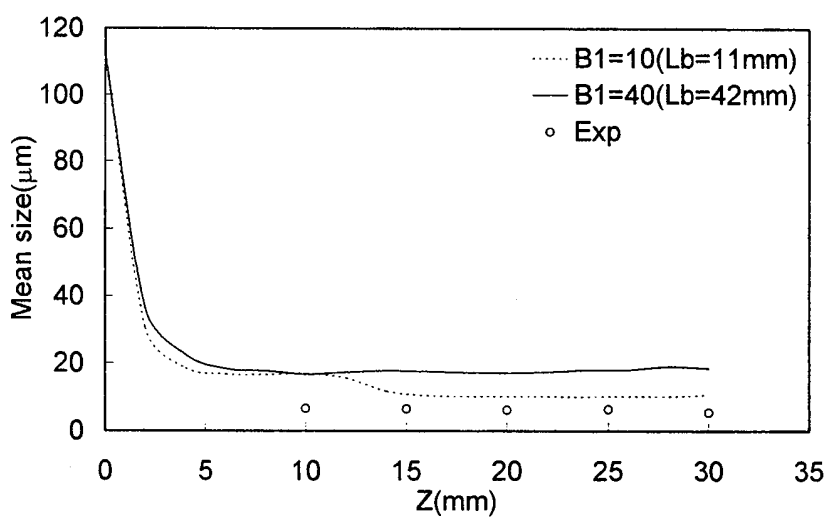

(b) Arithmetic mean size

Fig. 2 Spatial distribution of velocity and size

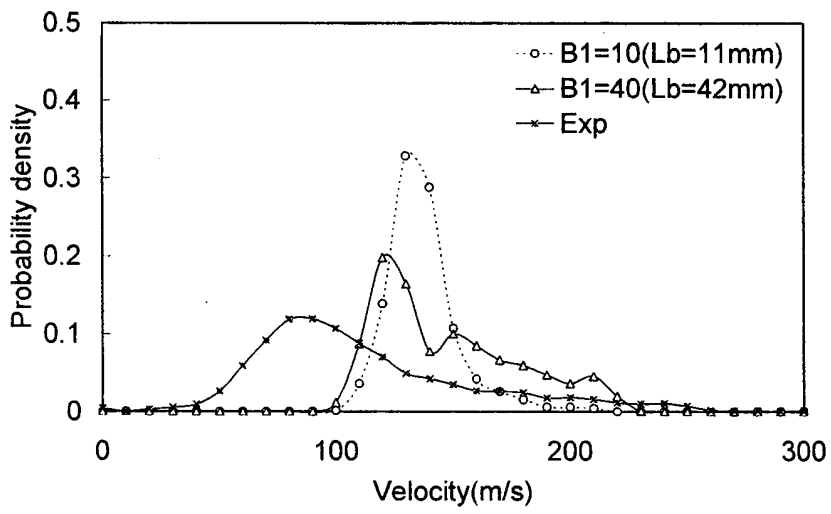

(a) Droplet velocity

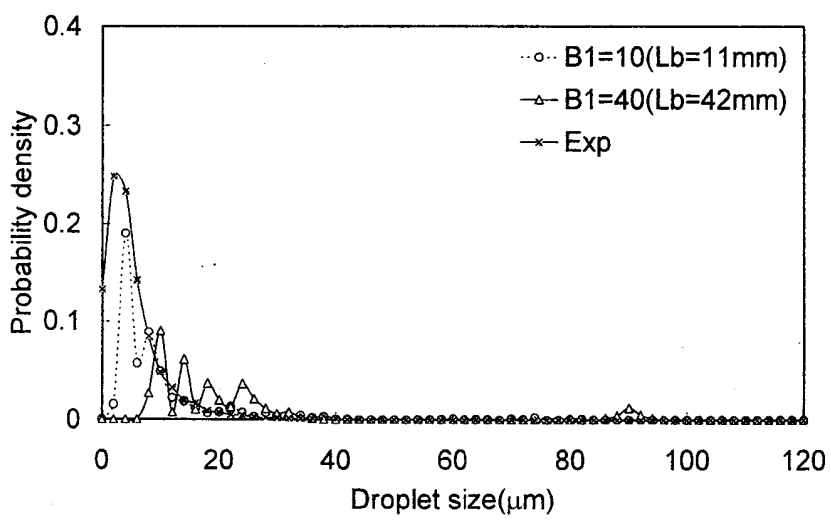

(b) Dropletsize

Fig. 3 Probability density of velocity and size; $z=30 \mathrm{~mm}$
図 5 および図 6 は噴射開始からクランク角 $1^{\circ}$ 後の燃焼室 内の数値解析結果であり、(a)が筒内ガス温度、(b)が液滴サイ ズを示している。 $B 1=40$ に低温度領域が確認できる。これは $B 1=10$ に比べ、分裂時間が遅いことから噴霧到達距離が長く、 噴霧の拡散が進行したため噴霧の蒸発が促進され $B 1=10$ より 早期に着火したと考えられる。

\section{5. まとめ}

KIVA-3V よる噴霧解析結果と L2F による液滴の速度および サイズの測定結果を比較し $\mathrm{KH}-\mathrm{RT}$ モデルにおける液滴分裂パ ラメータを検討するとともに、単気筒エンジンの燃焼試験を 燃焼解析結果と比較することにより、液滴分裂パラメータが 燃焼シミュレーションに及ぼす影響を明らかにした。

\section{6. 文献}

1. A.A.Amsden, Los Alamos Report, LA-12503-MS(1993)

2. A.A.Amsden,Los Alamos National Laboratory report, LA- 13313-MS(1997)

3. Ueki, H., Ishida, M., Sakaguchi,D.,SAE Paper No.2005-01-1238, pp.1-11(2005)

4. Yi, Y. and Reitz, R.D., SAE Paper No.2003-01-1041.

5. Jennifer and Reitz,R,D,Vol.9,pp.623-650,1990.

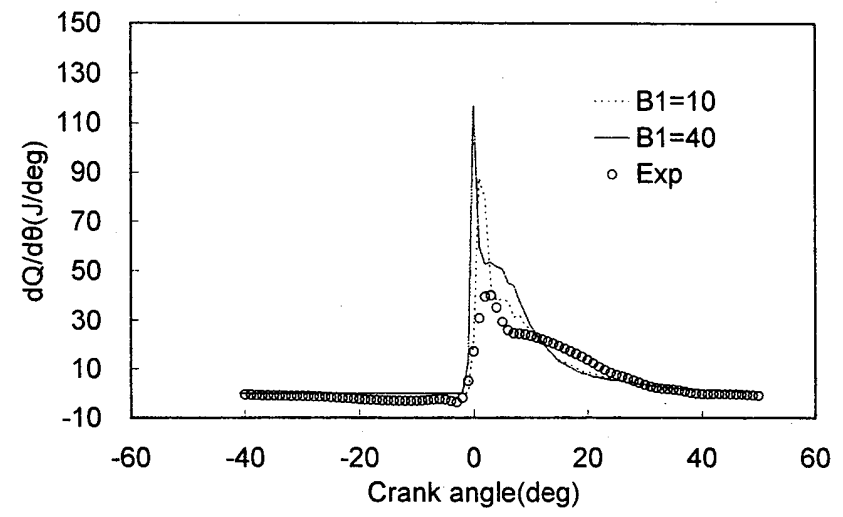

Fig. 4 Rate of heat release

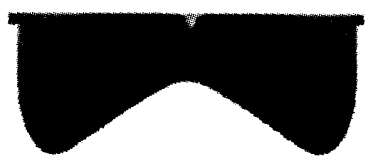

(a)Temperature

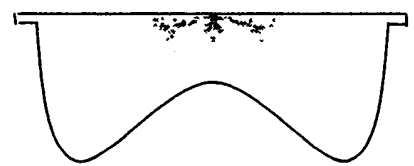

(b)Size
Fig. 5 Simulation; B1=10

\section{Low temperature region}

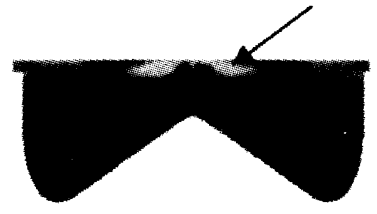

(a)Temperature

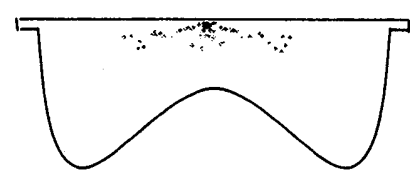

(b)Size 